Two parasites play the leading rôles in this procession, the Spirochata pallida, and the itch-mite. If the patient has syphilis, he is asked if he wishes to enter the hospital, and if he has scabies, the physician inquires if he is married or single. If the patient is married, he is advised to include his wife and family in the treatment. The necessary questions and commands are uttered with the automatism of a church service, and the whole affair passes along with cinematographic rapidity.

It is easy, however, to be a critic, especially an adverse critic. Every one should be judged by what he has accomplished, and undoubtedly the French are doing a good day's work in medicine, and especially in diseases of the skin.

It is interesting to watch these long lines of almost naked human beings advancing toward the phrsician, who is to order for one tar, for another mercury, for another resorcin, and for still another sulphur as an amelioration or a cure. In Genesis it is stated man is made of clay. Human beings are, therefore, according to this view, nothing but animated pottery, and on the surface of these stronger or weaker vessels one may see different designs; on one a patchy sealiness indicating psoriasis, and on another papules curiously formed and arranged, spelling out clearly the diagnosis svphilis; in ret another, lichen; and in still another, pediculosis. It must be said that these spots and splaslies of color, and rococo outbuddings are more fantastic than artistic, but their correct interpretation becomes. after a time. as interesting as any game or employment in which the perceptive faculties are actively called into play.

The physicians here are the same as in other parts of the world, in that they do a great deal of good work gratuitously, but in following St. Paul's advice to distribute to the necessity of saints, they find that the comforted saints often exhibit a frail side. $A s$ an instance of this, I ran across a curious industry in the St. Ionis Hospital. A patient would apply for treatment, and receivc the appropriate medicine free of charge. Then he would promptly march off to a drug-store and sell it. Those suffering from srphilis are said to he particularly iniquitous, and the little proto-iodid of mercurr pills are easily disposed of. It mar be objected that these are nnt saints, but in truth ther are, for repentance is of the very essence of sainthood. and fittingly to repent it is necessary first to accumulate a good stock of sin, together with a good admixture of misery. The woll-fed, comfortable sinner, like the king in Hamlet, stops short of complete repentance, and therefore caninot attain the crown of sainthood. It is to these shattered hulks. dismasted and battered br the storms of lipe that Rabelais dedicates his great book. It was such as these that stirred the sympathies of the greatest Seotchman that ever lived, and inspired him to write the great poem. "The Jolly Beggars." Many of the patients in the clinic of the St. Ionis Hospital looked as if they could eat a dinner. and without waiting for the recommendatory preface of a benediction either.

323 Geary Street.

Medical Inspection of Schools.-Medical inspection is becoming a vital part of every modern system of education. To obtain valuable results accurate data are necessary. It is escential that thorough supervision be made by a state medical inspector, who should be a medical man. A state association of medical inspertors should be formed. Permanent efficiency will require skilled workmen. careful arministration and adequate remuneration. W. J. Lamson, in Journal of the Medical Society of Nex Jersey.

\section{THE TEACHING OF VISCERAL ANATOMY, OR ORGANOLOGY}

JERTMIAH S. FERGUSON, M.S., M.D.

Assistant Professor of Histology, Cornell Cniversity Medical College NEW YORK

Medicine as a science is yet in its infancy ; its composite development, its evolution, forms a steadily increasing curve, but each of its component parts form irregular curves with frequent rises, falls and stationary levels, when historically considered. The close of the last century marked the completion of a period of ranid development in surgical science, during which it was, perhaps, eminently desirable that the medical student should view anatomy with exaggerated reference to its surgical importance.

The beginning of the present century offers promise of an equally important development on the side of internal medicine. The former necessity is now superseded by the latter, and for the internist an accurate and extensive familiarity with visceral anatomy is of fundamental importance.

If there was a time when students could be allowed to devote weeks to the careful dissection of an arm or a leg and then for want of time pass cursorily over the abdominal contents and perhaps fail entirely to open the thorax, cranium or spinal canal, that time is past: the demands of the internist in the present generation call not only for careful risceral work in the dissecting-rnom but for an amplification of that course by such methods as shall result in accurate conceptions of living structure, which in turn can result only from the familiarity obtained through extensive first-hand acquaintance witi, the tissues themselves. It is for the satisfaction of these demands that courses modeled along the lines which I am about to indicate must be offered to the medical student of to-day.

The form, position and external relations of the organs are best obserred in the "fixed" material of the dissecting-room, and if only recently prepared or carefully preserved tissue is used, the conception in the mind of the student will be well formed. But it is escential that the tissue be perfectly preserved and that the dissection shall be so rapid and careful as to allow no opportunity for excessive evaporation with coincident changes of color, texture and size. Even at its best, proserved dissecting-room material will show considerable changes in color and some hardening of texture. Material which has lain for weeks on the table during the dissection of the limbs and body wall, mnless it hias received the best of care, is not entirely satisfactory for the proper study of the viscera. To obtain the best results from the standpoint of organology a borly freslily prepared by injection should be brought directly from the preparation room, its paries at once opened, as at autopsy, and its riscera carefully survered, as rapidly as is consistent with thoroughness, first for their position and general relations and then for form and structure. Such organs as are not badly altered by disease should then be remored, their connections to paries and to adjacent organs and especially their vascular connections being carefully noted; then their surface marlings are to be carefully observed and their architecture thoroughly studied. Even at the loss of some material the finer details of dissection involving the topographic anatony of the organ will be better pursued on other material.

But even at its best, dissecting-room material only partially fulfils the requirements of an accurate concep- 
tion of the living viscera. Accurate conceptions and exact knowledge of any matter are obtained only by intimate first-hand acquaintance with the material. Abundance of opportunity for handling anatomic material should be afforded the student; no source of supply slould be neglected. A course in organology is therefore incomplete unless it utilizes an abundance of fresh tissue, which only the autopsy room can supply. Since the nearest approach to the actual living organs obtainab!e for anatomic study is found in the human tissues at antopsy, and in the fresh tissues of the lower animals, both of these sources should be extensively utilized for the purposes of organology.

'The recently dead animal presents organs, to all intents and purposes, in a living condition. In certain cases their cells can be transplanted and caused to grow; indeed, they may even be cultivated extraneously as has been demonstrated by R. G. Harrison and others.

'The fact that the lower mammalian organs differ anatomically from the human is not an objection to their utilization, for, indeed, the very differences may often be used to broalen the conception of human structure. The fact that the sheep's kidney is lobulated, or that the kirlney of the horse or dog has but one pyramid does not detract from the value of either in demonstrating the structural relations and appearance of the living human kidney, and if properly utilized they respectively elucidate a logical conception of the markings on the surface and the contents of the sinus of the human organ. Again, the objective study of the surface markings of the adult human lung is difficult of interpretation without reference to the child, the infant, and the lower animals.

But while lower animal tissues may be of great value in the demonstration of certain structural features they cannot be relied on as material for any great portion of such a course as is under discussion. Human anatomy must be primarily taught from human material. The handling and study of unaltered human material from the autopsy room offers the most valuable instruction to the anatomic student.

The utilization of this source of material cannot be left till such time as the student may pursue his work in the autopsy room under the instruction of the pathologist, for there he will be concerned, not with anatomic details, but with pathologic lesions, and his facility in pathologic study will largely depend on the accuracy and fulness of his anatomic conceptions, and on his familiarity with the structure and appearance of the normal rather than diseased viscera.

The result of a pedagogic experience of some years has convinced me of the fundamental importance of anatomic instruction based on fresh human tissue. A student of anatomy cannot see too much material of this kind; he should use it for most careful study.

Much normal tissue is removed at autopsy by the pathologist; with proper cooperation it should find its way, while still fresh, to the department of anatomy. A course in organology based on such material, amplified by the use of lower mammalian and other animal tissues, by museum specimens carefully prepared to preserve form, color, and to show the vital appearance, as nearly as possible, of certain special features of anatomic structure, and the whole broadened by coincident demonstrations on dissecting-room material which has been carefully and freshly prepared with organs fixed in situ, offers to the student of anatomy a well-nigh ideal opportunity for developing an accurate conception of the human body as it actually exists in a functionally active condition. \{
That such a course is utopian is not true. The fact that just such a course has been offered for the past three sessions in the laboratories of the Cornell University Medical College demonstrates its feasibility. 'The essentials are some time and energy on the part of the corps of anatomic instruction, and a very little friendly cooperation on the part of the pathologists. The time demanded from the student is little, because what is consumed in actual work renders so rich a return in improved knowledge of structure and of general, fundamental, anatomic characters that the work of the dissecting-room, and especially of the microscopic laboratory may thereby be very materially abbreviated. For this reason such a course in organology is best taught in connection with microscopic anatomy and the work so correlated that the gross anatomy of the organ immediately precedes its histology.

'The consideration of the value of a course in organology on the above lines directs attention at once to ccrtain phases of the relative value of the didactic and laboratory types of instruction. The value of the former type depends on the assumption that known facts are more readily obtained by the novice through the recorded observations of his predecessors, while the laboratory type presupposes that an accurate and utilizable knowledge must result only from personal contact with the object of study.

For this last type of work a progressively increasing value is represented by the book, the model, and the actual material. Given unlimited time and unlimited matcrial, a trained student has little need of other sources of information. But for the great bulk of medical students time in the laboratory is not unlimitel; hence the intensity of the laboratory work is greatly enhanced if accompanied by ample opportunity for reading and reflection in study hours. In the course which I have hitherto offered, the work of the student is also greatly facilitated by the use of a brief syllabus which indicates the names of structures of anatomic interest, without comment or description, arranged in the order in which they are uncovered.

With such opportunity it is remarkable how rapidly an accurate systematic conception of an organ may be acquired. In the laboratories of the University of Chicago it has been found that the study of the human brain is not only simplified but accelerated by a preliminary examination of the less complex nervous system of the dogfish, and the course is therefore begun with the dissection of the selachian nervous system. A true conception of the general fundaments, the gross divisions of structure as it were, renders the more intricate and complicated system so much more readily mastered as to result in an actual saving of time to the student as well as in a more utilitarian knowledge of the subject.

Likewise, in my laboratory at the Cornell University Medical College the survey of the fundaments of structure represented by gross organology as outlined above rendered possible an actual shortening of the time allotted to microscopic anatomy, and, far more important, I believe that the student better appreciates the full structure of the organs so studied. It is a matter of observation that he turns from his anatomy to his physjology better prepared to apply his anatomic knowledge to the deduction and explanation of function than was possible under other conditions. When one has studied in the gross the bundle of $\mathrm{His}$ and its ramifications, seen it in the fresh tissue, as well as in the dissected specimen and the microscopic section, and all have been properly correlated by coincident study, he has a preparation for 
the consideration of heart-block which cannot be obtained by the isolated work of the dissecting-room or the histologic laboratory. When those courses have been corjelated by the study of the conduction system in fresh tissue and the transference of bits of known location to the stage of the microscope for verification of structure, the student thus prepared is in full possession of the anatomic mechanism, so far as it concerns the bundle in question, on which the phenomenon of heart-block largely depends.

A course in organology based on fresh material is, therefore, closely related to the work of the microscopic laboratory, and for him who pursues it the utmost of value is only obtainable when the facilities of the autopsy, the dissecting-room, and the microscopic laboratrry have been coincidently placed at his disposal. With the organization of broad-minded departments of anatomy with gross and microscopic work provided for under the same head, an arrangement now generally adopted in leading medical schools at home and abroad, such correIation of work appears entirely feasible and eminently desirable.

330 West Twenty-Eighth Street.

\section{THE EDUCATIONAL FUNCTION OF HOS- PITALS AND THE HOSPITAL YEAR *}

JAMES B. HERRICK, M.D.

\section{CHICAGO}

The central figure in every hospital is, or should be, the patient. Whatever use is made of the hospital as a means of education it should be self-understood that whenever the sick man enters it he has a right to expect and demand the most skilled treatment its staff can offer. We physicians believe that the best treatment will be in the hospital that clearly recognizes its educational function. But if the patient be utilized for the instruction of nurses, undergraduate or graduate medical students. or in the working out of some scientific problem, there must be assurance that his life is not endangered or his health impaired thereby. We may use him as "material," to employ the word that unfortunately has become fixed in our medical vernacular, but not as we use a Wheatstone bridge, a burette, a test-tube, a guinea-pig or a uabhit. We assert that it is our right and duty to experiment with inanimate apparatus, and-when we are humane-with the lower animate bodies, even though the test-tube break or the rabbit die. But a human being is neither a test-tube nor a guinea-pig. We may study his disease, even experimentally, but we must treat him as a fellow-man.

A modern hospital fully awake to its privileges and with the high aim to do the greatest possible amount of good will strive to educate: (1) undergraduates; (2) interns, graduate or undergraduate; (3) resident physicians and surgeons; (4) the attending staff; (5) nurses; (6) research workers; (7) the patient; (8) the public.

\section{UNDERGRADUATE INSTRUCTION}

Undergraduate medieal instrnetion can best be carried on in a hospital founded primarily for educational purposes, and especially one under the immediate control of a medical school. The student's presence in the ward is not looked on as an intrusion or as due to favoring con* IRad lofore the Seventh Annual Conference of the Councid on
Mredical Education of the American Medical Association, March 1, 1911 descension on the part of the hospital authorities. He is there by right; he makes examinations, acts as clerk in recording changes in the patient from day to day, is laboratory assistant, etc. And yet he is without authority to prescribe for or to treat the patient. He makes no promiscuous examinations. $\mathrm{He}$ is watched and guided and does no harm. He follows the case during the conrse of the illness. A student carefully observing and studying even a small number of cases of illness, even though the maladies be simple, compelled to keep complete records that are scrutinized daily by his superior, has learned more of correct methods and of practice, perhaps more even of fact, than from hours and hours of lectures.

In the majority of our public hospitals the lax methods. the multitude of students, the prejurlice against the use of the patient as "material," the politician's fear of criticism, the failure to provide capable and responsible supervision, make students' ward work very unsatisfactory or wholly impossible. Much is often accomplished by means of small-group clinies with the student at the berside as the case is demonstrated, or by ward walks as in Fngland. And much is done by the arena clinic, no longer popular as of old, but by no means entirely out of date, and still fulfilling a useful though subordinate purpose.

\section{INSTRUCTION OF INTERNS}

Of the value of an internship in a good hosnital, where, in addition to the student's clerical and laboratory work, there is actual responsibility, usually a graded responsibility, i. e., one increasing with his length of service, there is no question. No one who has had the advantage of such a training doubts its value; no one who has not had it but regrets his inability to secure it. The eager competition among our raw graduates for these positions shows the estimate placed on them by our student body.

Sooner or later some period of training - say a vearin a hospital should be required of every student before he beemes a licentiate in medicine. If the time is ripe it should be demanded now. We must command the supmort of the public in this advance by making them sec that if the young graduate does not giain his practical experience in a hospital under the guidance of older heirls, and in an atmosphere redolent of traditional malical knowledge handed down from one generation of interns to another, and from one group of attendino men to another-and this traditional knowledge is one of the most valuable assets of a hospital-if he does not get his training in this safe-guarded manner before he is a licenerel practitioner, he is forced to get it in his private practice on your child or on mine and with no counseling voice of senior to keep him from sins of omission or commission.

The marvel is that so many men with utter lack of hospital training are able to go out and do so well-i. e., do so little harm. Native shrewdness, earnest endeavor, tact, ability to learn quickly from others and from their. own mistakes, enable them to succeed in a wonderful manner. How many sad, even fatal, blunders are male through lack of proper practical training no one can tell-it is best not to tell. Even the celebrated Irr. San Grado wished Gil Blas to go about with him for a few days on his rounds of bleeding and drenching his patients with water before the said Gil Blas was to bo permitted to practice as the representative of San Gralo.

The difficulties in the way of a required fifth hospital year are not insurmountable. More internships must be available to accommodate our large annual output of 